\title{
Population Dynamics of Sugarcane Moth Borers In Indonesian Cane Fields
}

\section{Dinamika Populasi Hama Penggerek Tebu di Indonesia}

\author{
Nader Sallam ${ }^{1}$, Etik Achadian $^{2}$, Ari Kristini $^{2}$, Rob Magarey $^{3}$ and Emily Deomano ${ }^{4}$ \\ ${ }^{1}$ Sugar Research Australia, Gordonvale, Australia; \\ ${ }^{2}$ Indonesian Sugar Research Institute, Pasuruan, Indonesia; \\ ${ }^{3}$ Sugar Research Australia, Tully, Australia; \\ ${ }^{4}$ Sugar Research Australia, Indooroopilly, Australia \\ Correspondent authors: NSallam@ sugarresearch.com.au
}

\begin{abstract}
We conducted monthly monitoring of lepidopterous moth borers in four sugarcane fields in Java, Indonesia, from May 2009 to May 2011. Fields sampled belonged to Pesantren Baru, Jombang Baru, Gondang Baru and Subang sugar factories. Three main moth borer species were found to inflict damage to sugarcane plantations in all regions, and these are the stalk borers Chilo sacchariphagus (Bojer) and Chilo auricilius Dudgeon and the top borer Scirpophaga excerptalis (Walker). Tetramoera (Eucosma) schistaceana (Snellen) was also encountered but only caused minor damage. Borer populations increased with plant age and reached a peak around January - May in most cases, with the onset of rainfall triggering population rise. All borers coexisted in the same plant with no evidence of competition between the two stalk borers ( $C$. sacchariphagus and $C$. auricilius) over their specific feeding location (internode) or between the two stalk borers and the top borer ( $S$. excerptalis) over the same plant. This suggests that an infestation by one species does not make the plant less desirable to be colonised by another. Parasitism rates by natural enemies were very low which reflects the challenges facing biological control efforts in Java. Knowledge generated through this project will improve our understanding of borer dynamics in South East Asia and will enhance our preparedness for potential introduction by any of these pests into Australia.
\end{abstract}

Key words: monitoring, sugarcane, moth borer, population dynamic

\begin{abstract}
ABSTRAK
Monitoring bulanan populasi hama penggerek Lepidopteran telah dilakukan di empat kebun tebu di Jawa, Indonesia, mulai bulan Mei 2009 - Mei 2011. Kebun yang diambil sebagai sampel adalah kebun milik pabrik gula Pesantren Baru, Jombang Baru, Gondang Baru dan Subang. Ditemukan tiga spesies penggerek utama yang menyerang tanaman tebu di semua kebun, yaitu penggerek batang Chilo sacchariphagus (Bojer) dan Chilo auricilius Dudgeon serta penggerek pucuk Scirpophaga excerptalis (Walker). Tetramoera (Eucosma) schistaceana (Snellen) juga ditemukan, akan tetapi hanya menyebabkan kerusakan kecil. Populasi penggerek meningkat seiring umur tanaman dan mencapai puncaknya sekitar bulan Januari - Mei, curah hujan memicu peningkatan populasi. Semua jenis penggerek dapat hidup berdampingan pada tanaman yang sama, tanpa ada bukti persaingan antara dua
\end{abstract}


penggerek batang (C. sacchariphagus dan C. auricilius) pada ruas yang sama atau antara dua penggerek batang dan penggerek pucuk (S. excerptalis) pada batang yang sama. Hal ini menunjukkan bahwa serangan oleh satu spesies tidak membuat tanaman tidak terserang oleh spesies lain. Angka parasitisme musuh alami sangat rendah yang mencerminkan tantangan yang harus dihadapi dalam upaya pengendalian hayati di Jawa. Informasi yang dihasilkan melalui proyek ini dapat meningkatkan pemahaman tentang dinamika populasi penggerek di Asia Tenggara dan meningkatkan kesiapan untuk potensi masuknya OPT tersebut ke Australia.

Kata kunci: monitoring, tebu, hama penggerek, dinamika populasi

\section{INTRODUCTION}

The top borer Scirpophaga excerptalis (Walker) and the stalk borers Chilo sacchariphagus (Bojer) and C. auricilius Dudgeon (Lepidoptera: Crambidae) are the main species infesting sugarcane crops in Indonesia. S. excerptalis is responsible for the majority of dead heart symptoms in both young and mature cane, while $C$. auricilius and $C$. sacchariphagus cause dead hearts only in young cane and later tunnel inside the stalk damaging the internodes (Sallam et al., 2010). Several factors influence damage levels caused by borers ultimately in the field, which makes it difficult to precisely determine their economic impact on the crop. Varietal resistance/tolerance, abundance of natural enemies, weather patterns as well as farming practices such as planting and harvesting dates, the quality of planting material, fallow management and the level of general farm hygiene are all factors that influence borer populations in the field and their impact on yield (Sallam $e t$ al., 2014; Maneerat \& Suasa-Ard, 2015; Goftishu, et al., 2017; Goebel and Nikpay, 2018; Nikpay et al., 2020). In addition, a number of borer species coexist on the same plant and collectively damage the crop. Based on field trials in Indonesia, the collective impact of $S$. excerptalis, $C$. sacchariphagus and $C$. auricilius has been estimated by (Goebel et al., 2011) to result in a yield loss of $34.5 \%$. However, total crop destruction due to one or more borer species is not uncommon, and a number of sugarcane projects were terminated in West Papua due to total destruction caused by species of Chilo to preliminary plantations (Wilmar Sugar, personal communication).

Borer species occurring sympatrically may exercise interspecific competition over the same host plant. However, they may also avoid direct competition by either exploiting a different microhabitat or adapting to a different micro- or macroclimate. For instance, the spotted stalk borer, Chilo partellus (Swinhoe) (Lepidoptera: Crambidae) is capable of outcompeting C. orichalcociliellus (Strand) and Busseola fusca (Fuller) (Lepidoptera: Noctuidae) where the two species occur sympatrically in sub-Saharan Africa (Kfir, 1997; Ofomata et al., 2000). However, B. fusca was found to be the dominant borer attacking maize crops in the relatively colder highland regions, while $C$. partellus is most abundant in the warmer lowlands (Ntiri et al., 2016). On the other hand, several borer species still occur simultaneously in the field and collectively damage the crop. For example, both $C$. infuscatellus and $S$. excerptalis were 
recorded to coexist during January-April in Gujarat, India, while $C$. auricilius and $C$. sacchariphagus are both abundant from June to December in cane fields (Pandya, et al., 1996). Similarly, the African sugarcane borer Eldana saccharina (Lepidoptera: Pyralidae) is recorded to damage cane plants collectively with Chilo zacconius (Lepidoptera: Crambidae) and Sesamia sp. (Lepidoptera: Noctuidae) in Ghana (Sampson \& Kumar, 1986).

In an attempt to reduce reliance on insecticides for the combat of moth borers in Indonesia, Integrated Pest Management efforts have been established and extended to growers through ISRI entomologists and field staff. Major Indonesian sugar factories invest in biological control laboratories and parasitoid breeding and field release. Parasitoids such as Cotesia flavipes (Hymenoptera: Braconidae), Trichogramma spp. (Hymenoptera: Trichogrammatidae) and Sturmiopsis inferens (Diptera: Tachinidae) are frequently released in cane fields in most cane planting regions in (Sunaryo \& Suryanto, 1986; Sallam, 2006; Nurindah, et al., 2020). Furthermore, ISRI has instigated a number of pheromone trapping trials where the effectiveness of certain sex attractants sourced from P3GI sugar factory was evident in monitoring borer populations and supporting early warning systems (Achadian, et al., 2014). Knowledge of infestation timing and borer dynamics in the field is essential prior to the commencement of any IPM program. Our work was conducted to study the population dynamics of the main moth borer species in Java and to examine the coexistence potential of the three borers in the same field. In addition, the impact of natural enemies on borer populations has not been fully examined in Indonesia, and more work is needed to assess the role of the range of parasitoid species in a field situation. Knowledge generated through this work will improve the effectiveness of borer management programs, where appropriate timing of chemical, biological or pheromone trapping applications may be established. This knowledge will also improve our preparedness for exotic borers in Australia through better understanding of factors governing their dynamics in cane fields.

\section{METHODS}

Four sugarcane fields where borer abundance was evident were chosen for this study in Java, Indonesia. The fields were about one hectare each and belonged to Gondang Baru, Jombang Baru, Pesantren Baru and Subang sugar factories and were planted with varieties PS851, PS864, PS862 and PS951, respectively. These varieties showed moderate - high susceptibility to borers in a previous study with the exception of PS851 which sustained relatively low borer damage (Sallam et al., 2014). The study commenced shortly after planting or harvesting of the first crop, and field sampling was conducted monthly from May 2009 to May 2011 in all blocks. Fields were planted conventionally at a row spacing of 1.35 meters. In each field, 10 transects (10 meter long each and at least 5 rows apart) were selected randomly in each sampling occasion and 5 plants in each transect were sampled for borer abundance, making a total of 50 sampled plants/field. Numbers of dead hearts, damaged internodes and larval and pupal stages for each plant were recorded. Stalks that showed borer damage were sliced longitudinally and borer stages recovered. Pest stages obtained were taken to the laboratory and bred until they either 
produced adult moths or a parasitoid. The pest species or the emerged parasitoid was then identified by ISRI and SRA entomologists. If a borer stage was not found the species responsible for the damage could still be identified by examining the tunnel shape or the dead heart symptom. Plant age and rainfall levels (with a lag of $0,1,2$ or 3 months) were correlated with subsequent borer damage data using Pearson Correlation Coefficient. A linear model was fitted to borer counts and post-hoc mean comparisons were performed accordingly to compare the frequency of occurrence by one species with the frequency of occurrence by more than one species together at the plant, stalk or internode level (SAS Institute Inc. 2011).

\section{RESULTS AND DISCUSSION}

Three main moth borer species were encountered in all regions, and these are the stalk borers Chilo sacchariphagus (Bojer) and Chilo auricilius Dudgeon and the top borer Scirpophaga excerptalis (Walker) (Lepidoptera: Crambidae). A fourth borer species,Tetramoera (Eucosma) schistaceana (Snellen) (Lepidoptera: Tortricidae), was also encountered but caused minor damage, where larvae only fed externally on the internodes and around the buds in mature cane. This species was therefore excluded from the data analysis. Figures 1-3 show numbers of $S$. excerptalis, $C$. sacchariphagus and $C$. auricilius stages/plant in four sugarcane fields in Java over two consecutive seasons (2009-2011).

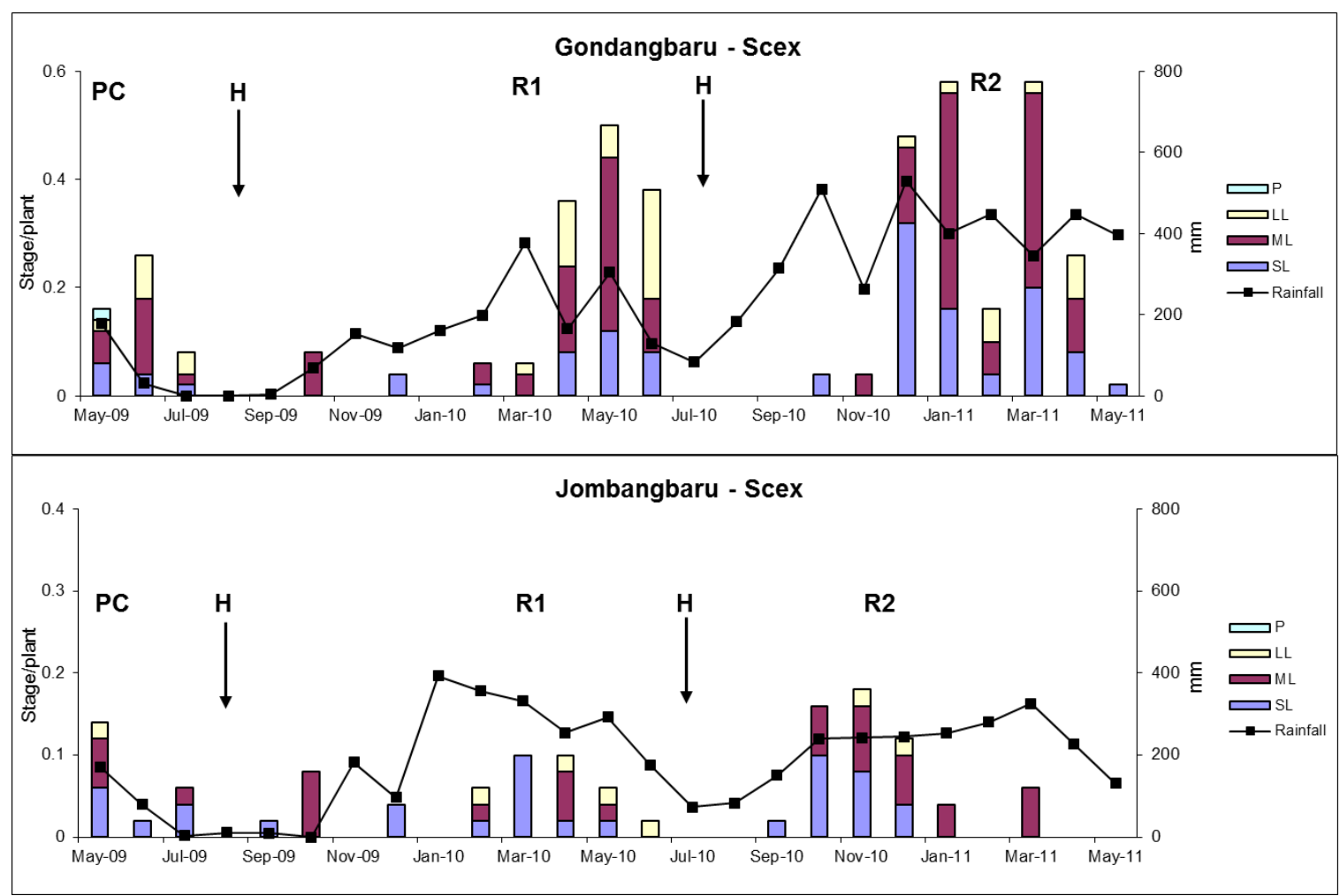




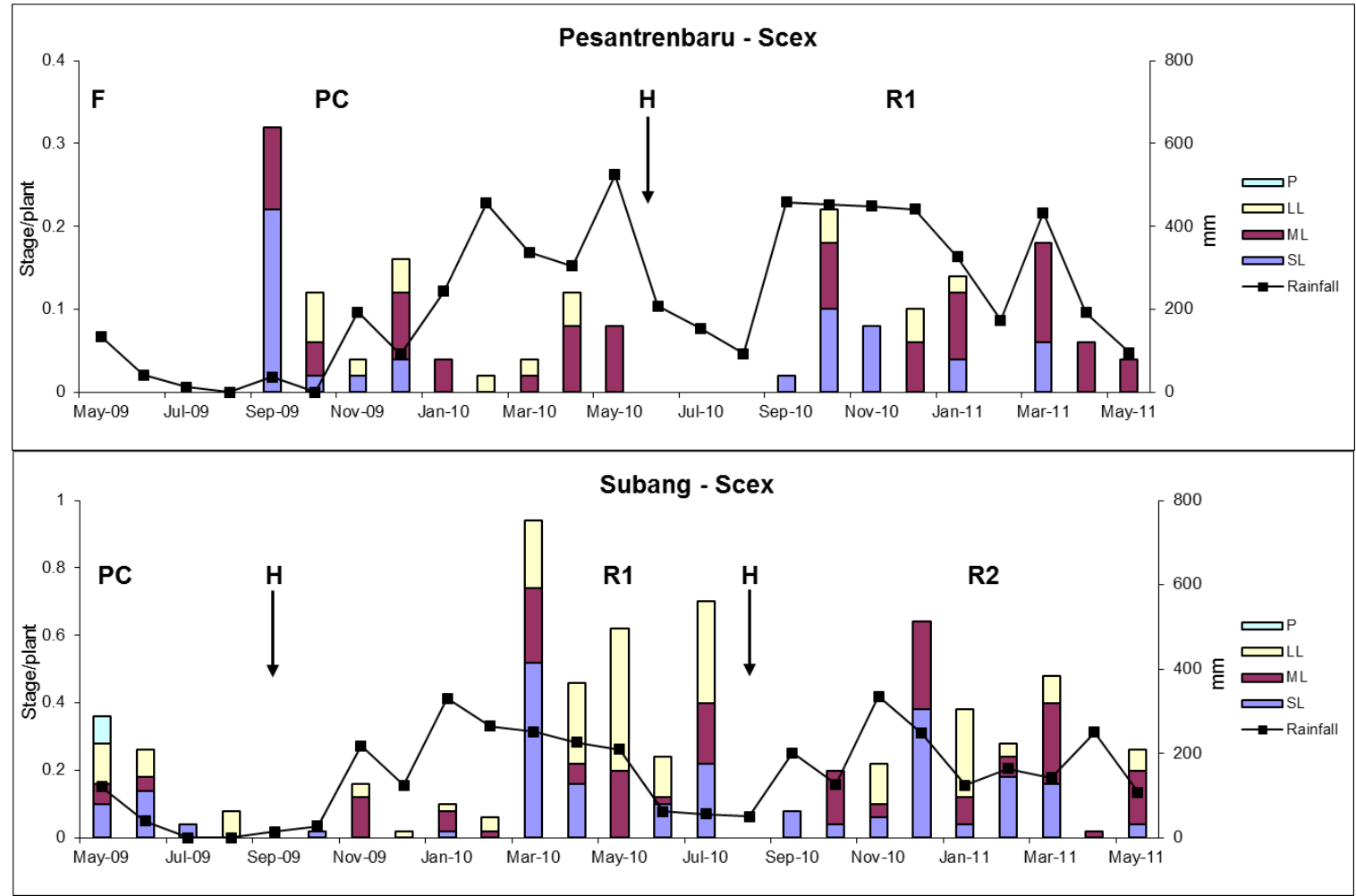

Figure 1. Number of $S$. excerptalis stages/plant in 4 sugarcane fields in Java over 2 consecutive seasons $(2009-2011)$. $\mathrm{PC}=\mathrm{Plant}$ cane; $\mathrm{H}=$ Harvest; $\mathrm{R} 1=1^{\text {st }}$ ratoon; $\mathrm{R} 2=2^{\text {nd }}$ Ratoon; $\mathrm{F}=$ Fallow; $\mathrm{P}=$ pupa; $\mathrm{LL}=$ large larva; $\mathrm{ML}=$ medium larva; $\mathrm{SL}=$ Small larva.

Gambar 1. Jumlah S. excerptalis per stadia per tanaman di 4 kebun tebu di Jawa selama 2 tahun (2009 - 2011). PC=Plant cane; H=tebang; R1=keprasan ke-1; R2= keprasan ke-2; F=bero; $P=$ pupa; $L L=$ larva besar; $M L=$ larva sedang; $S L=$ larva kecil

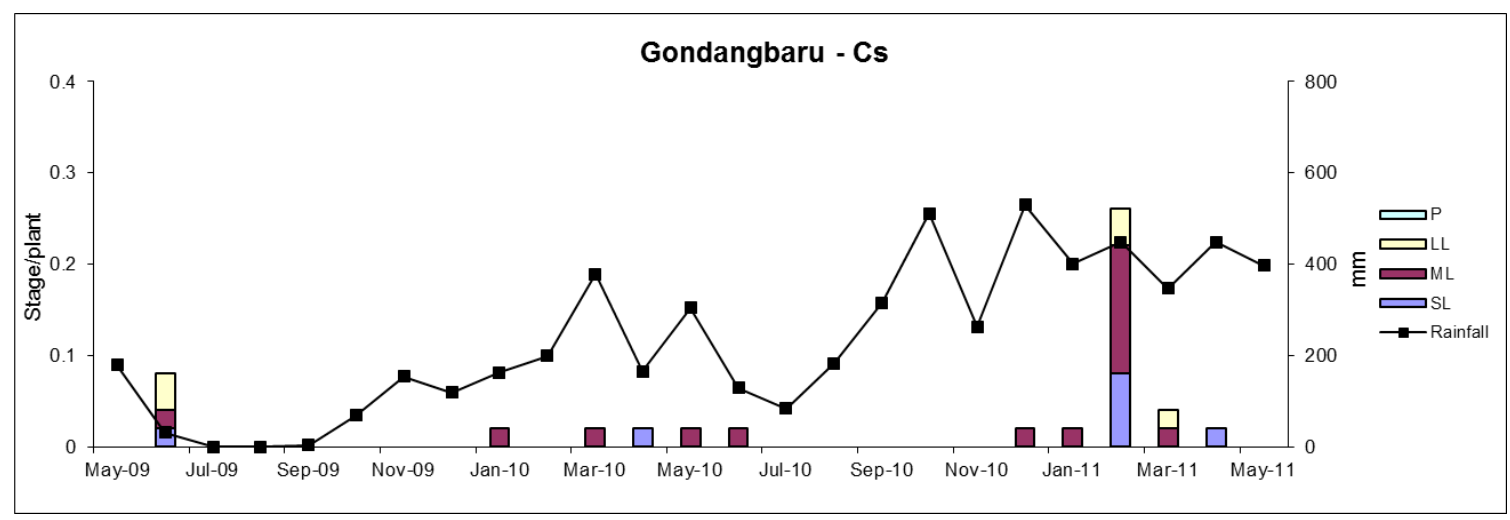




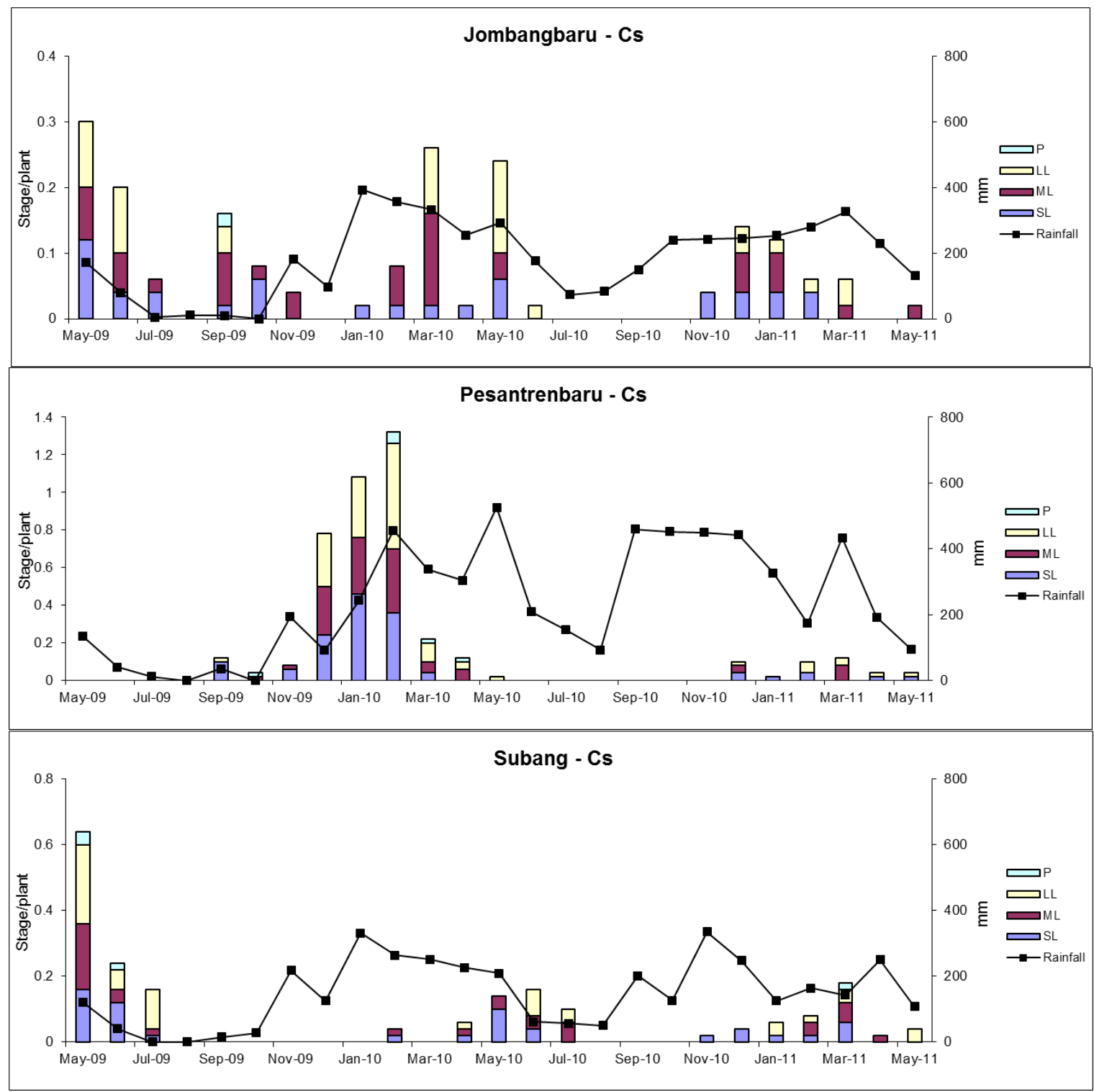

Figure 2. Number of $C$. sacchariphagus stages/plant in 4 sugarcane fields in Java over 2 consecutive seasons $(2009-2011)$. $\mathrm{PC}=\mathrm{Plant}$ cane; $\mathrm{H}=$ Harvest; $\mathrm{R} 1=1^{\text {st }}$ ratoon; $\mathrm{R} 2=2^{\text {nd }}$ Ratoon; $\mathrm{F}=$ Fallow; $\mathrm{P}=$ pupa; $\mathrm{LL}=$ large larva; $\mathrm{ML}=$ medium larva; $\mathrm{SL}=$ Small larva.

Gambar 2. Jumlah C. sacchariphagus per stadia per tanaman di 4 kebun tebu di Jawa selama 2 tahun (2009-2011). PC=Plant cane; H=tebang; Rl=keprasan ke-1; $R 2=$ keprasan ke-2; F=bero; $P=$ pupa; $L L=$ larva besar; $M L=$ larva sedang; $S L=$ larva kecil. 


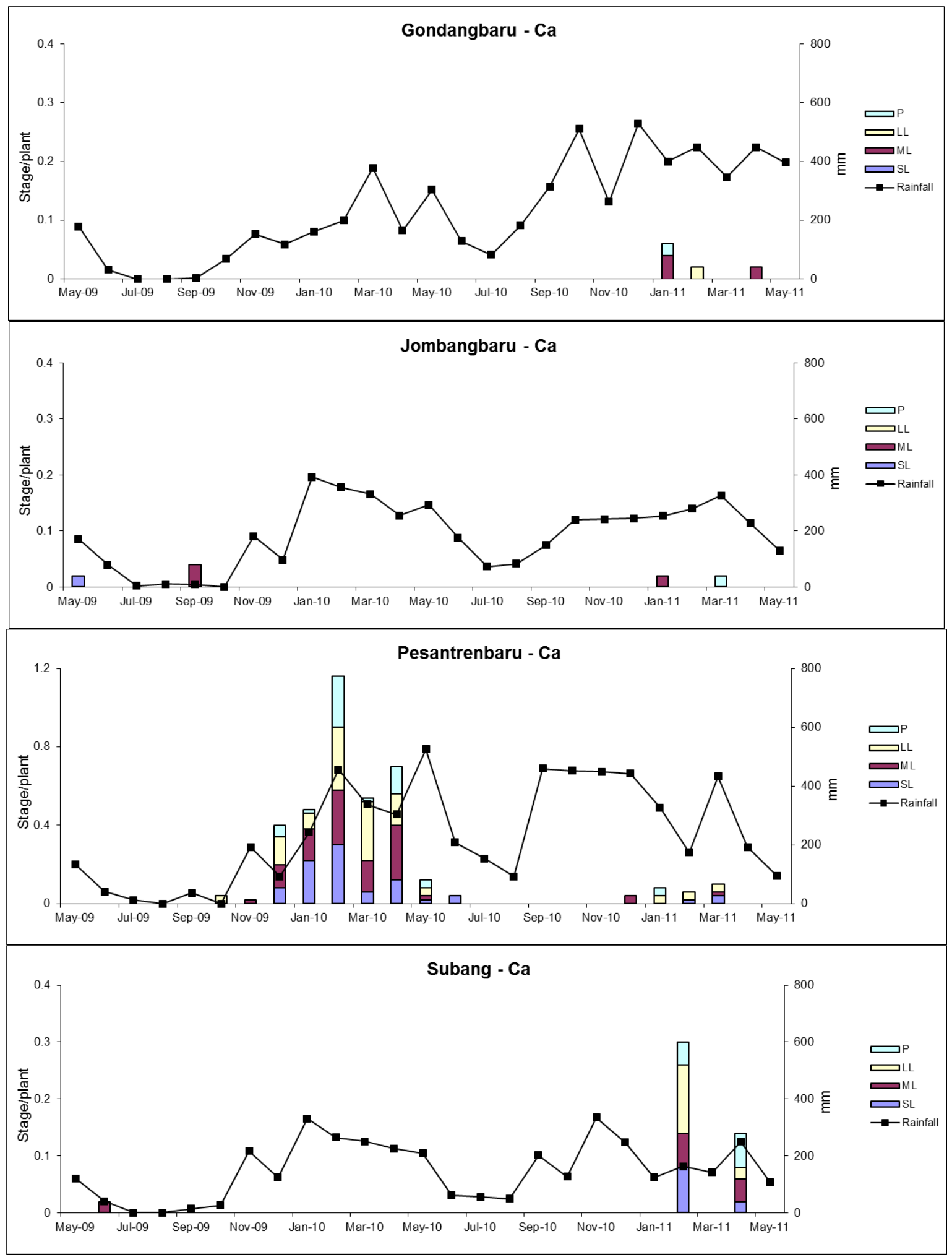

Figure 3.Number of $C$. auricilius stages/plant in 4 sugarcane fields in Java over 2 consecutive seasons $(2009-2011) . P C=P l a n t$ cane; $H=$ Harvest; $R 1=1^{\text {st }}$ ratoon; $R 2=2^{\text {nd }}$ Ratoon; $\mathrm{F}=$ Fallow; $\mathrm{P}=$ pupa; $\mathrm{LL}=$ large larva; $\mathrm{ML}=$ medium larva; $\mathrm{SL}=$ Small larva.

Gambar 3. Jumlah C. auricilius per stadia per tanaman di 4 kebun tebu di Jawa selama 2 tahun (2009 - 2011). PC=Plant cane; H=tebang; R1=keprasan ke-1; R2= keprasan ke-2; F=bero; $P=$ pupa; $L L=$ larva besar; $M L=$ larva sedang; $S L=$ larva kecil. 
Figures 4 and 5 showed the number of dead hearts/plant caused by all borers and numbers of internodes damaged/plant by $C$. sacchariphagus and $C$. auricilius over the same study period. Scatter diagrams (Figures 6) showed larval stages of $S$. excerptalis and $C$. sacchariphagus to start appearing in the field about 50 days after planting/ratooning and to continue until harvest, while larvae of $C$. auricilius started later in the season when plants were about 150 days old and continued until harvest.

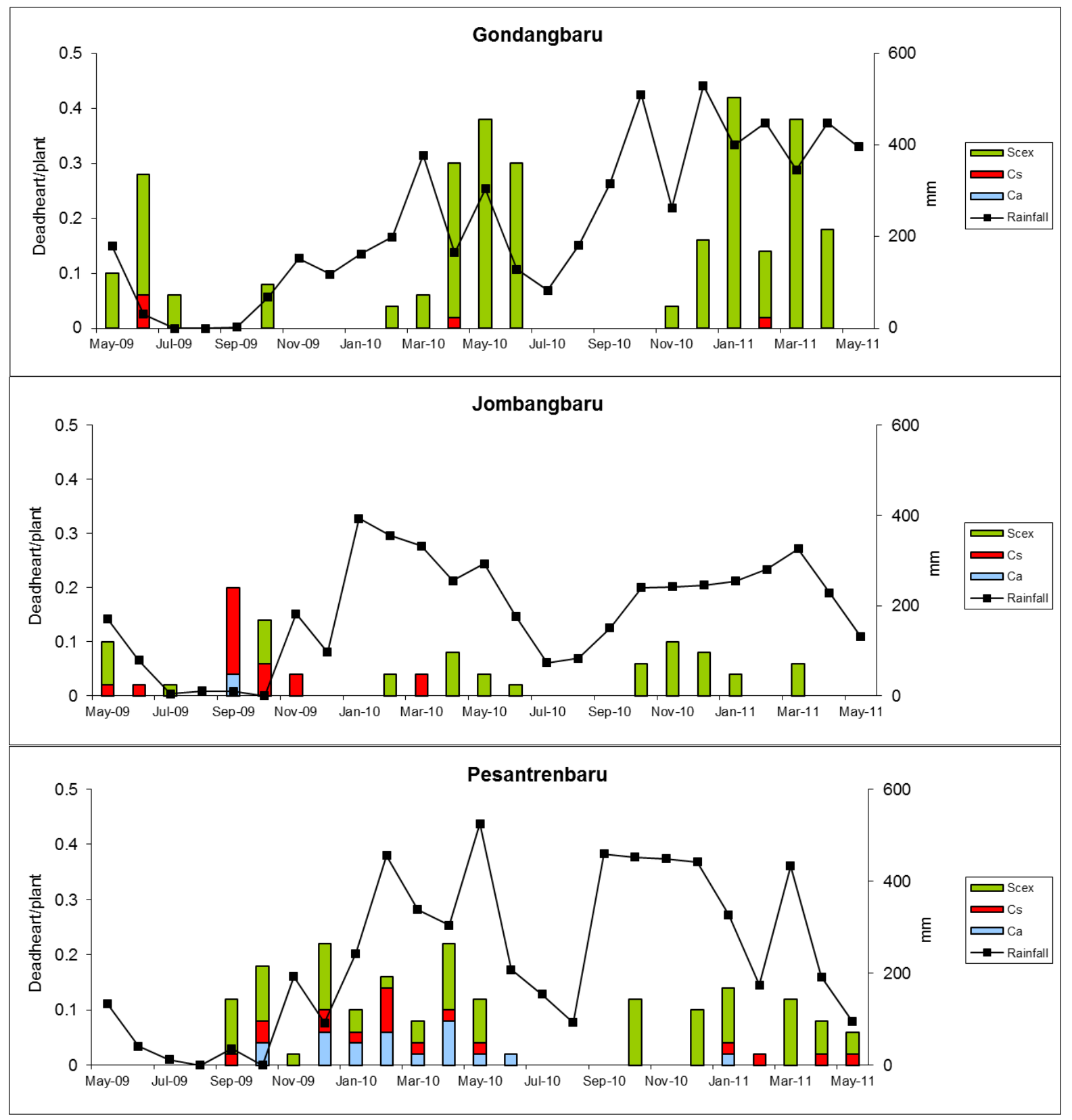




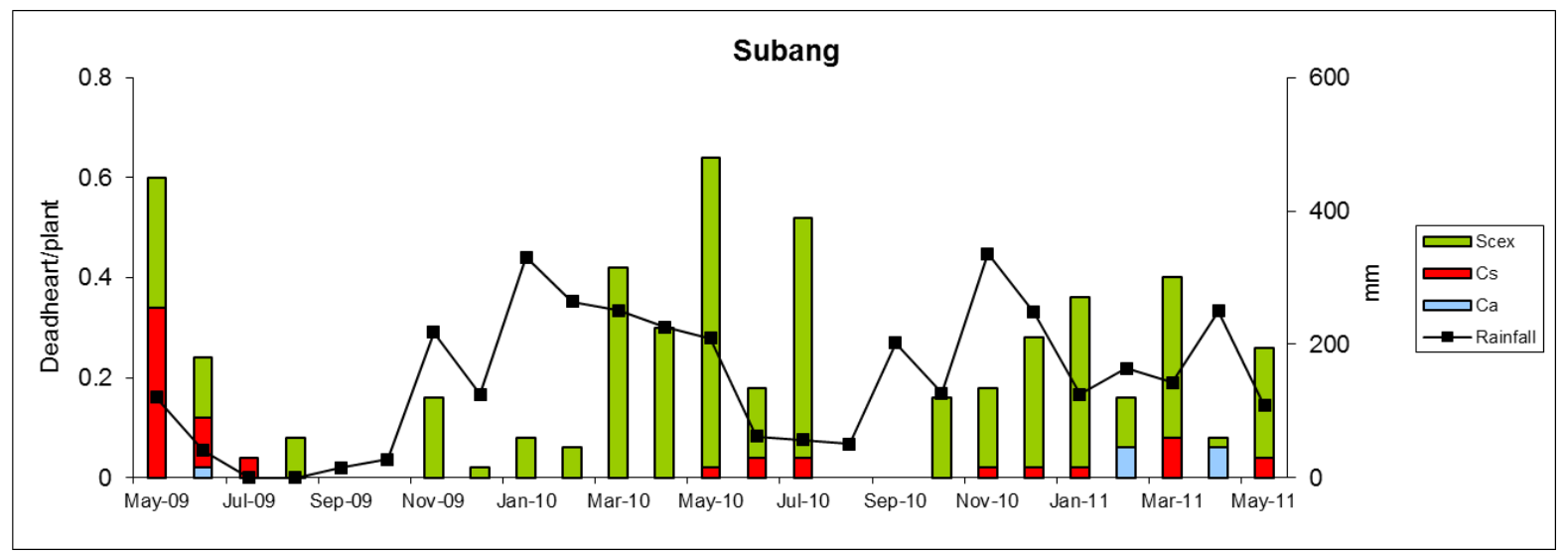

Figure 4. Number of dead hearts/plant caused by S. excerptalis (Scex), C. sacchariphagus (Cs) and $C$. auricilius $(\mathrm{Ca})$ in 4 sugarcane fields in Java over 2 consecutive seasons $(2009-2011)$. $\mathrm{PC}=\mathrm{Plant}$ cane; $\mathrm{H}=$ Harvest; $\mathrm{R} 1=1^{\text {st }}$ ratoon; $\mathrm{R} 2=2^{\text {nd }}$ Ratoon; F=Fallow.

Gambar4. Jumlah tanaman mati puser karena serangan S. excerptalis (Scex), $C$. sacchariphagus (Cs) dan C. auricilius di 4 kebun tebu di Jawa selama 2 tahun (2009-2011). PC=Plant cane; H=tebang; Rl=keprasan ke-1; $R 2=$ keprasan ke-2; F=bero

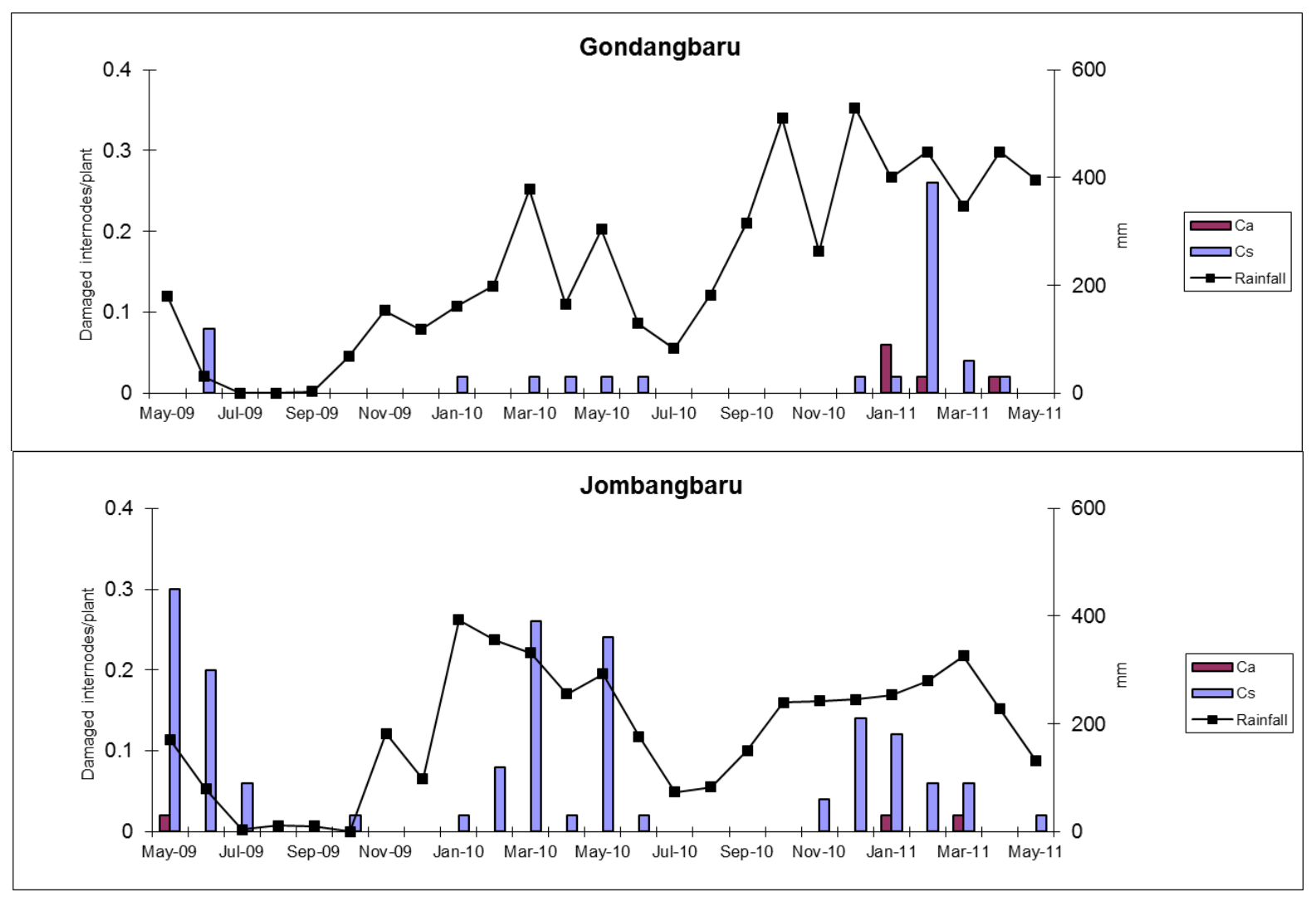




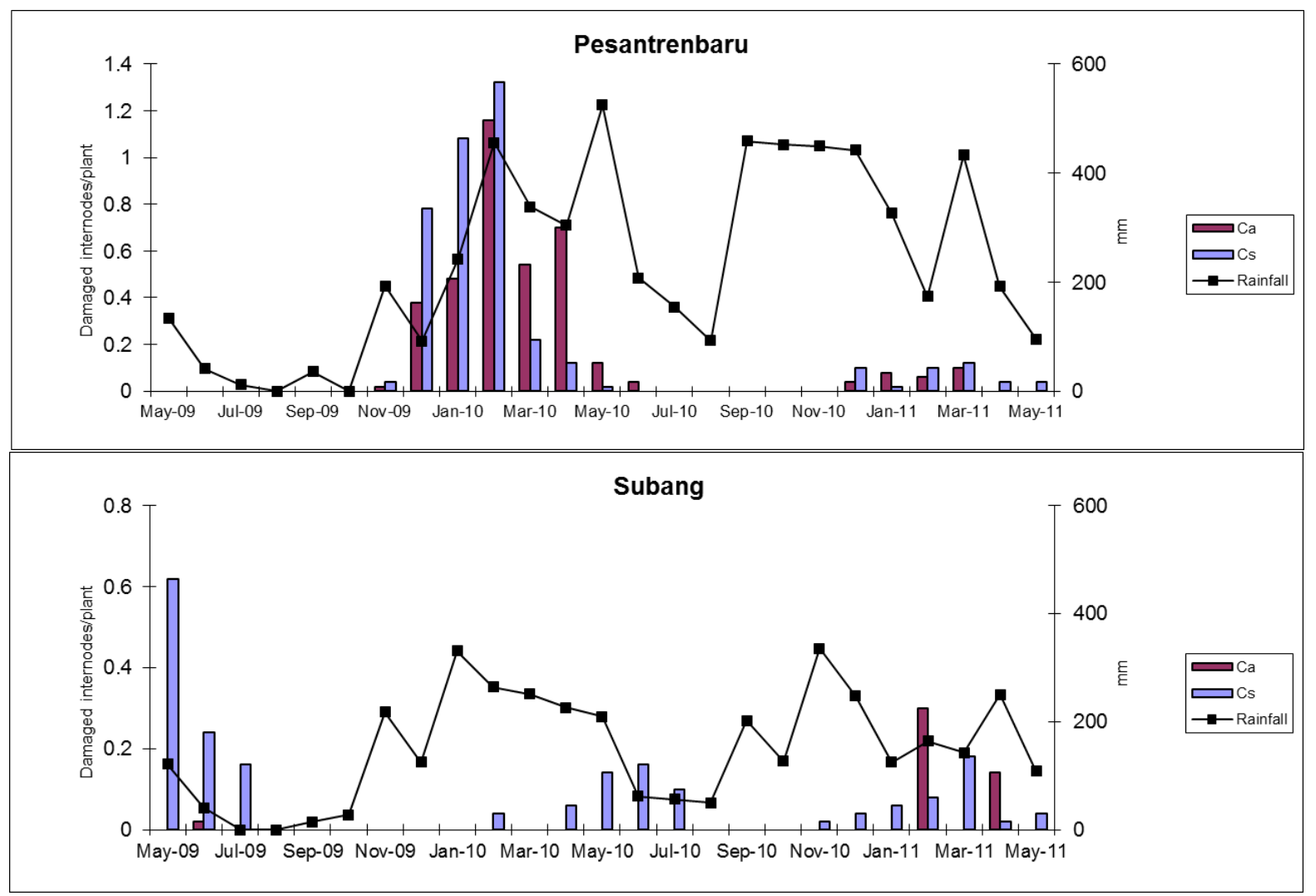

Figure 5. Number of damaged internodes/plant caused by C. sacchariphagus (Cs) and $C$. auricilius $(\mathrm{Ca})$ in 4 sugarcane fields in Java over 2 consecutive seasons (2009 2011). $\mathrm{PC}=$ Plant cane; $\mathrm{H}=$ Harvest; $\mathrm{R} 1=1^{\text {st }}$ ratoon; $\mathrm{R} 2=2^{\text {nd }}$ Ratoon; $\mathrm{F}=$ Fallow.

Gambar 5. Kerusakan ruas tebu karena serangan C. sacchariphagus (Cs) dan C. auricilius di 4 kebun tebu di Jawa selama 2 tahun (2009 - 2011). PC=Plant cane; $H=$ tebang; $R 1=$ keprasan ke-1; $R 2=$ keprasan $k e-2 ; F=$ bero
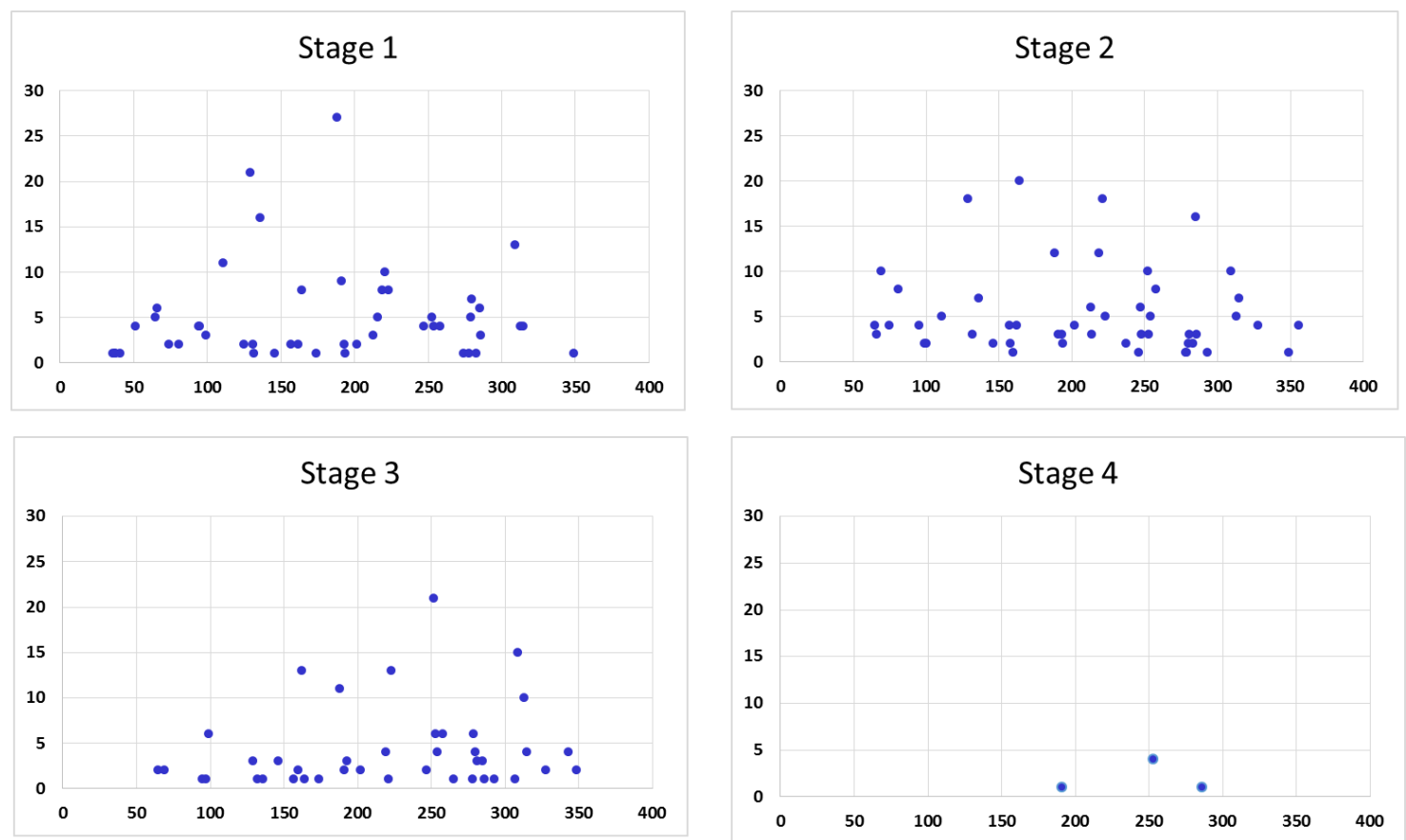

A 

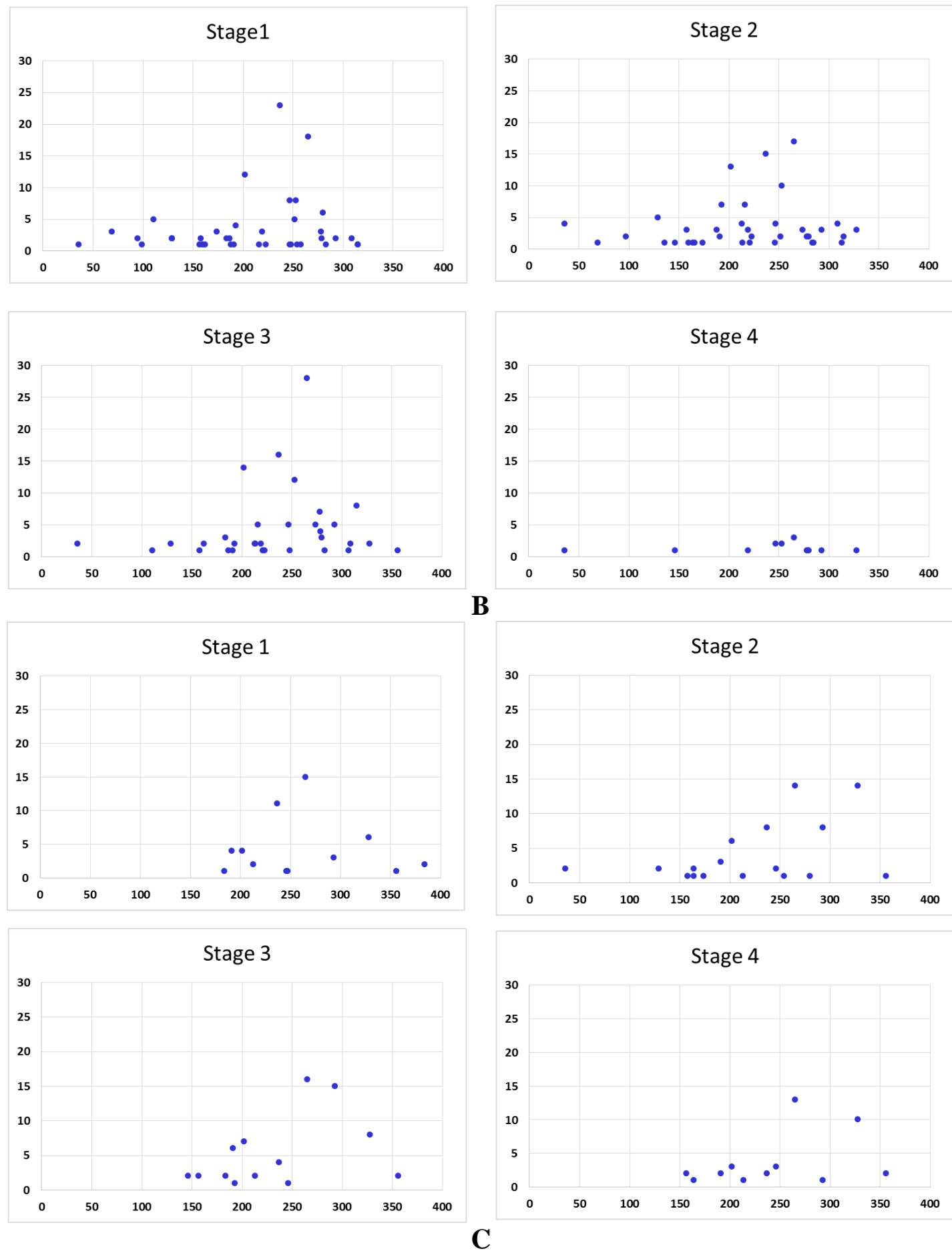

Figs 6. Total number of immature stages (vertical axis) of $S$. excerptalis (A), $C$. sacchariphagus (B) and C. auricilius (C) recovered from 4 sugarcane fields in Java in relation to crop age in days (horizontal axis) over the entire period of study (2009 - 2011). Stage1=Young larva; Stage 2=medium larva; Stage 3=Large larva; Stage 4=Pre-pupa and pupa.

Gambar6. Jumlah total stadia muda (aksis vertikal) penggerek S. excerptalis (A), C. sacchariphagus $(B)$ dan C. auricilius $(C)$ di 4 kebun tebu di Jawa dalam kaitannya dengan umur tanaman dalam hitungan hari (aksis horizontal) selama periode penelitian (2009 - 2011). Stadium1 = larva kecil; Stadium2= larva sedang; Stadium3= larva besar; Stadium4= pre-pupa dan pupa 
Our study showed that the onset of rainfall triggers borer infestation and that borer numbers are correlated with cane age. This agrees with studies on C. infuscatellus, C. tumidicostalis and S. excerptalis which showed borer infestation to escalate during the growing stages of the crop then decline slightly before harvest in Indian cane fields (Borah \& Sarma, 1995; Sing \& Varma, 1995; Madan, et al., 1999). While studies in Haryana, India, showed that infestation by C. auricilius and S. excerptalis is positively correlated with maximum temperature, relative humidity and rainfall (Sardana \& Das, 2001). Our study also showed that all borer species readily coexist on the same plant, which means that an infestation by one borer does not make the plant less desirable to be colonised by another. This might therefore support earlier studies which suggested that selecting tolerant/resistant varieties to more than one borer species may be feasible (Sallam et al., 2010). While the top borer $S$. excerptalis exploits a different microhabitat (growing point) to the stalk borers (mature stalks), it might be the case that the two Chilo species avoid direct competition by adapting to different macroclimatic conditions. Previous work by (Sallam et al., 2010) suggested that C. sacchariphagus is more adapted to wetter regions whereas $C$. auricilius is more tolerant to dry conditions. In addition, the late onset of infestation by $C$. auricilius relative to $C$. sacchariphagus might be another competition avoiding mechanism, however it might also mean that $C$. sacchariphagus infested plants are more vulnerable to infestation by $C$. auricilius. Nevertheless, C. sacchariphagus is by far the dominant stalk borer species currently in
Indonesia and is the one responsible for the majority of internode damage in cane fields (Sallam et al., 2010). It is also not clear if the Indonesian population of $C$. auricilius is the same species considered to be one of the most damaging pests of sugarcane in northern India. C. auricilius is also recorded to be a key pest of rice in Bangladesh and parts of India and China (Husain \& Begum, 1985; Neupane, 1990; Meng et al., 1997). Yet the Indonesian population has always been known to mainly feed on sugarcane until (Hattori \& Siwi, 1986) reported it feeding on rice in Java and South Kalimantan. DNA phylogenetic studies are currently underway to assist in understanding the status of each of these species and, ultimately, ensure the establishment of pest specific management strategies (Lange, et al. 2004; Braithwaite, et al., 2016) (Andrew Mitchell, Personal communication).

Borer populations and respective damage reached a peak between January May in most cases. There was a significant positive correlation between plant age and dead heart symptoms (caused by $S$. excerptalis) and bored internodes caused by C. sacchariphagus and C. auricilius, indicating infestation progression towards time of harvest (Table 1). There was a positive delayed relationship between rainfall and subsequent internode damage by $S$. excerptalis and $C$. sacchariphagus two or three months later in Gondang Baru and Jombang Baru, while in Subang damage levels were significantly correlated with 'same month' rainfall. This correlation was not significant in case of $C$. auricilius in mostly all regions (Tables 2 and 3). 
Table 1. $\mathrm{P}$ values indicating correlation between plant age and internode damage caused by C. sacchariphagus (C.s.) and C. auricilius (C.a.) and dead heart symptoms caused by $S$. excerptalis in 4 sugarcane fields in Java.

Tabel 1. Nilai P menunjukkan korelasi antara umur tanaman dan kerusakan ruas oleh serangan C. sacchariphagus (C.s.) and C. auricilius (C.a.) serta gejala mati puser oleh serangan S. excerptalis di 4 kebun tebu di Jawa.

\begin{tabular}{|l|c|c|c|}
\cline { 2 - 4 } \multicolumn{1}{c|}{} & \multicolumn{3}{c|}{ P } \\
\cline { 2 - 4 } \multicolumn{1}{c|}{} & \multicolumn{2}{c|}{$\begin{array}{c}\text { Internode damage } \\
\text { Kerusakan ruas }\end{array}$} & $\begin{array}{c}\text { Dead heart } \\
\text { Mati puser }\end{array}$ \\
\cline { 2 - 4 } & C.s & C.a & S.e. \\
\hline Gondang Baru & $<.0001^{*}$ & $0.0095^{*}$ & $<.0001^{*}$ \\
\hline Jombang Baru & $<.0001^{*}$ & $<.0001^{*}$ & $<.0001^{*}$ \\
\hline Pesantren Baru & $<.0001^{*}$ & $<.0001^{*}$ & $0.015^{*}$ \\
\hline Subang & $0.0001^{*}$ & 0.6041 & $<.0001^{*}$ \\
\hline
\end{tabular}

Table 2. P values indicating correlation between rainfall and dead heart symptoms caused by $S$. excerptalis in 4 sugarcane fields in Java.

Tabel 2. Nilai P menunjukkan korelasi antara curah hujan dan mati puser oleh serangan $\mathrm{S}$. excerptalis di 4 kebun tebu di Jawa.

\begin{tabular}{|c|c|c|}
\hline Factory & Lag (months) & \\
Pabrik gula & Lag (bulan) & $\mathrm{P}$ \\
\hline \multirow{4}{*}{ Gondang Baru } & 0 & 0.0654 \\
\cline { 2 - 3 } & 1 & 0.7508 \\
\cline { 2 - 3 } & 2 & 0.3027 \\
\cline { 2 - 3 } & 3 & $0.0045^{*}$ \\
\hline \multirow{4}{*}{ Jombang Baru } & 0 & 0.3295 \\
\cline { 2 - 3 } & 1 & 0.4843 \\
\cline { 2 - 3 } & 2 & 0.0667 \\
\hline \multirow{3}{*}{ Pesantren Baru } & 3 & $0.0143^{*}$ \\
\cline { 2 - 3 } & 0 & 0.5138 \\
\cline { 2 - 3 } & 1 & 0.3729 \\
\cline { 2 - 3 } & 2 & 0.06 \\
\hline \multirow{3}{*}{ Subang } & 3 & 0.1445 \\
\cline { 2 - 3 } & 1 & $0.0032^{*}$ \\
\cline { 2 - 3 } & 2 & 0.2186 \\
\cline { 2 - 3 } & 3 & 0.1245 \\
\hline
\end{tabular}


Table 3. P values indicating correlation between rainfall and internode damage caused by $C$. sacchariphagus (C.s.) and C. auricilius (C.a.) in 4 sugarcane fields in Java.

Tabel 3. Nilai P menunjukkan korelasi antara curah hujan dan kerusakan ruas oleh serangan C. sacchariphagus (C.s.) and C. auricilius (C.a.) di 4 kebun tebu di Jawa.

\begin{tabular}{|c|l|l|l|}
\hline \multirow{2}{*}{$\begin{array}{c}\text { Factory } \\
\text { Pabrik gula }\end{array}$} & Lag (months) & \multicolumn{2}{|c|}{ Pag (bulan) } \\
\cline { 2 - 4 } & 0 & C.s & \multicolumn{1}{|c|}{ C.a } \\
\hline \multirow{5}{*}{ Gondang Baru } & 1 & 0.9528 & 0.485 \\
\cline { 2 - 4 } & 2 & 0.3689 & 0.1889 \\
\cline { 2 - 4 } & 3 & 0.0662 & 0.1209 \\
\hline \multirow{5}{*}{ Jombang Baru } & 0 & $0.0437^{*}$ & 0.0942 \\
\cline { 2 - 4 } & 1 & 0.451 & 0.1601 \\
\hline \multirow{5}{*}{ Pesantren Baru } & 2 & 0.1118 & 0.0804 \\
\cline { 2 - 4 } & 3 & $0.0025^{*}$ & $0.043^{*}$ \\
\cline { 2 - 4 } & 0 & $0.0008^{*}$ & 0.104 \\
\hline \multirow{4}{*}{ Subang } & 2 & 0.181 & 0.0772 \\
\cline { 2 - 4 } & 3 & 0.0837 & 0.1853 \\
\hline & 0 & 0.4153 & 0.4251 \\
\cline { 2 - 4 } & 1 & 0.7515 & 0.9382 \\
\cline { 2 - 4 } & 2 & $0.0098^{*}$ & 0.5947 \\
\cline { 2 - 4 } & 3 & 0.0813 & 0.6187 \\
\hline
\end{tabular}

Where all borer species occurred simultaneously in one plot, there was no significant difference between borer counts when the occurrence frequency of $S$. excerptalis alone was compared to its occurrence together with $C$. sacchariphagus and $C$. auricilius on the plant level $(\mathrm{T}=0.54$, $\mathrm{df}=8, \mathrm{P}=0.607)$ or stalk level $(\mathrm{T}=0.59, \mathrm{df}=$ $8, \mathrm{P}=0.57)$. Similarly, there was no significant difference when the combined occurrence of $C$. sacchariphagus and $C$. auricilius was compared to the occurrence of each species individually on the internode level $(\mathrm{T}=1.25, \mathrm{df}=5, \mathrm{P}=0.26)$.

Species of parasitoids that were recovered from the collected borers are shown in table 4. All obtained parasitoids attacked the larval stage, and no egg or pupal parasitoids were encountered. Overall parasitism rates were unexpectedly very low and were typically less than $5 \%$ in almost all cases. A few exceptions were Cotesia flavipes Cameron (Hymenoptera: Braconidae) on $C$. sacchariphagus in Subang (2009) and in Pesantren Baru (2010) where parasitism rates were $14.28 \%$ and $12.96 \%$ respectively, and in Jombang Baru (2009) where parasitism rate by Diatraeophaga striatalis Towns. (Diptera: Tachinidae) was $15.55 \%$ on the same species. D. striatalis was also responsible for $25.0 \%$ parasitism rate on C. auricilius in Jombang Baru (2009). 
Table 4. Number of parasitised individuals indicated (if $>0$ ) next to the total number of immature borer stages (in brackets) recovered from 4 sugarcane fields in Java. $\mathrm{Ds}=$ Diatraeophaga striatalis Towns; $\mathrm{Cf}=$ Cotesia flavipes Cameron; $\mathrm{Ij}=I$ sotima javensis (Rohwer); $\mathrm{Ce}=$ Campyloneurus erythrothorax Szepligeti ; $\mathrm{St}=$ Stenobracon sp.; Ez=Elasmus zehntneri Ferrière.

Tabel 4. Jumlah ulat penggerek yang diamati (dalam kurung) dan jumlah individu yang terparasit (jika > 0) ditunjukkan oleh angka sesudahnya, di 4 kebun tebu di Jawa. $D s=$ Diatraeophaga striatalis Towns; $C f=$ Cotesia flavipes Cameron; Ij=Isotima javensis (Rohwer); $C e=$ Campyloneurus erythrothorax Szepligeti ; $S t=$ Stenobracon $s p . ; E z=$ Elasmus zehntneri Ferrière.

\begin{tabular}{|c|c|c|c|c|c|}
\hline $\begin{array}{c}\text { Factory } \\
\text { Pabrik gula }\end{array}$ & \multicolumn{3}{|c|}{ C. auricilius } & $\begin{array}{c}C . \\
\text { sacchariphagus }\end{array}$ & S. excerptalis \\
\hline \multirow{3}{*}{$\begin{array}{c}\text { Gondang } \\
\text { Baru }\end{array}$} & \multicolumn{2}{|l|}{2009} & $(0)$ & (4) & (33) \\
\hline & \multicolumn{2}{|l|}{2010} & (0) & (5) & (97) \\
\hline & \multicolumn{2}{|l|}{2011} & $(5)$ & $(17)$ & $(82)$ \\
\hline \multirow{7}{*}{$\begin{array}{c}\text { Jombang } \\
\text { Baru }\end{array}$} & \multirow{3}{*}{2009} & Ds & (4) 1 & $(45) 7$ & (19) \\
\hline & & $\mathbf{C f}$ & (4) & (45) 4 & (19) \\
\hline & & $\mathbf{I j}$ & (4) & $(45)$ & (19) 1 \\
\hline & \multirow{3}{*}{2010} & Ds & $(0)$ & (42) 2 & $(41)$ \\
\hline & & $\mathbf{C f}$ & $(0)$ & (42) 1 & $(41)$ \\
\hline & & $\mathbf{I j}$ & $(0)$ & $(42)$ & (41) 1 \\
\hline & 2011 & Ds & $(2)$ & (13) 1 & $(5)$ \\
\hline \multirow{7}{*}{$\begin{array}{c}\text { Pesantren } \\
\text { Baru }\end{array}$} & 2009 & $\mathbf{C f}$ & $(25)$ & (51) 1 & $(32)$ \\
\hline & \multirow{3}{*}{2010} & Ds & (193) 13 & $(162) 4$ & $(36)$ \\
\hline & & $\mathbf{C f}$ & (193) 9 & (162) 21 & (36) \\
\hline & & $\mathrm{Ce}$ & (193) 4 & $(162) 2$ & $(36)$ \\
\hline & \multirow{3}{*}{2011} & Ds & (12) 3 & $(16)$ & $(21)$ \\
\hline & & $\mathbf{C f}$ & $(12)$ & (16) 1 & $(21)$ \\
\hline & & St & $(12)$ & $(16)$ & (21) 1 \\
\hline \multirow{10}{*}{ Subang } & \multirow{3}{*}{2009} & $\mathbf{C f}$ & $(1)$ & $(56) 8$ & $(57)$ \\
\hline & & Ij & $(1)$ & $(56)$ & $(57) 1$ \\
\hline & & St & $(1)$ & $(56)$ & (57) 1 \\
\hline & \multirow{3}{*}{2010} & $\mathbf{C f}$ & $(0)$ & (29) 3 & $(216)$ \\
\hline & & Ij & $(0)$ & $(29)$ & (216) 2 \\
\hline & & $\mathbf{E z}$ & $(0)$ & $(29)$ & (216) 5 \\
\hline & \multirow{4}{*}{2011} & $\mathbf{C f}$ & $(22)$ & (19) 3 & $(74)$ \\
\hline & & $\mathbf{I j}$ & (22) & (19) & (74) 3 \\
\hline & & $\mathbf{E z}$ & (22) & (19) & (74) 2 \\
\hline & & St & (22) & (19) & (74) 3 \\
\hline
\end{tabular}

Reasons for the very low rates of parasitism are unknown. Laboratory trials in Java demonstrated that approximately $40 \%$ of $C$. flavipes fertile females failed to lay eggs in $C$. sacchariphagus or $C$. auricilius larvae (Sallam, unpublished data). More 
work is needed to examine the reasons for the lack of natural parasitism in the field by the range of parasitoids and to assess the value of biological control programs in Indonesia. It needs to be stated that the role of Trichogramma spp. egg parasitoids was not assessed due to the difficulty of encountering borer egg batches in the field. Furthermore, the calculated parasitism rates may slightly underestimate actual field rates. This is due to the latent mortality of a fraction of the collected larvae in the lab after collection. In addition, some larval parasitoids may be more attracted to a certain larval stage (i.e. medium or large), while percentage parasitism was calculated in proportion to the total number of obtained larvae.

Chemical or biological control may be most effective if deployed as borer populations begin to rise, which according to our study is between 50 -150 days after planting or time of harvest for $C$. sacchariphagus and S. excerptalis, and after 150 days for $C$. auricilius. It is not clear based on our study when the best time to release stage-specific natural enemies is, since all immature stages were abundant over an extended period of time through the duration of the crop. However, the population peak for $S$. excerptalis small, medium and large larval stages was observed 150, 200 and 250 days after planting, respectively, while this was evident 250 days after planting for $C$. sacchariphagus and 250 - 300 days after planting for $C$. auricilius. This information will be useful in determining when to commence a parasitoid release program, which should be well before a population peak occurs. In addition, targeted field sampling when plants are between $50-150$ days of age will further assist in deciding on accurate timing of stage-specific parasitoid release.

\section{CONCLUSION}

Knowledge gained during this study will improve our understanding of the dynamics of these borer species in cane fields, and will enhance our quarantine measures accordingly. With sugarcane plantations expanding in South East Asia, it is in Australia's interest to maintain strong research and surveillance activities in that region. Australia's engagement in sugarcane research and development in South East Asia will benefit industries in this region and will also ensure a safe and secure sugarcane industry in Australia.

\section{ACKNOWLEDGMENTS}

The authors wish to thank the managers and staff members of all the sugar factories where this work has been conducted in Indonesia. Thanks are also due to Indonesian Sugar Research Institute (ISRI) manager and staff who helped with field and laboratory work. Finally, the authors are grateful to the Australian Centre for International Agricultural Research (ACIAR) and Sugar Research Australia (SRA Limited) for jointly funding this research project.

\section{REFERENCES}

Achadian EM, Bambang, TR, Tarno H, \& Goebel FR (2014) 'Efektivitas Feromon Seks Sintetis Sebagai Alat Monitoring Populasi Hama Penggerek Pucuk Tebu Scirpophaga excerptalis walk. (Lepidoptera: Pyralidae)', $M P G, 50$, pp. 24-34. 
Braithwaite K, Chandler K \& Sallam N (2016) 'Barcoding: A tool to assist the industry to manage insect incursionsNo Title', International Sugar Journal, 118(1411), pp. 516521.

Borah BK \& Sarma KK (1995) 'Seasonal incidence of Plassey borer, Chilo tumidicostalis Hmpsn. in ratoon sugarcane', Plant Health, 1, pp. 2933.

Goebel, F. R. et al. (2011) 'Investigation of crop losses due to moth borers in Indonesia', 33rd Annual Conference of the Australian Society of Sugar Cane Technologists 2011, ASSCT 2011, 33, pp. 136-144.

Goebel, F. R. and Nikpay, A. (2018) 'Integrated pest management in sugarcane cropping systems.', Integrated pest management in tropical regions, (December), pp. 113-133. doi: 10.1079/9781780648002.0113.

Goftishu M, Assefa Y, Niba A \& Fininsa C (2017) 'Cereal stem borer management practices in subsistence farms of eastern Ethiopia', International Journal of Pest Management, 63(4), pp. 289-298.

Hattori, I and S. S. Siwi (1986) 'Rice stemborers in Indonesia.', JARQ, 20, pp. 25-30.

Husain M \& Begum N. (1985) 'Seasonal stem borer (SB) population fluctuations in Mymensingh, Bangladesh', International Rice Research Newsletter, 10(5), p. 22.

Kfir, R. (1997) 'Competitive displacement of Busseola fusca (Lepidoptera: Noctuidae) by Chilo partellus (Lepidoptera: Pyralidae)', Annals of the Entomological Society of America, 90(5), pp. 619-624. doi: 10.1093/aesa/90.5.619.

Lange CL, Scott KD, Graham GC, S. N. \& A. P. (2004) 'Sugarcane moth borers (Lepidoptera: Noctuidae and
Pyraloidea): phylogenetics constructed using COII and 16S mitochondrial partial gene sequences', lBulletin of Entomological Research, pp. 457-464. doi: http://doi.org/10.1079/ber2004320.

Madan YP, Singh D \& Singh M. (1999) 'Extent of damage, losses and control of sugarcane top borer, Scirpophaga excerptalis Walker. (Pyralidae: Lepidoptera).', Indian Sugar, 48(11), pp. 912-920.

Maneerat, T. and Suasa-ard., W. (2015) 'Population trends of sugarcane moth borers and their larval parasitoid, Cotesia flavipes cameron (hymenoptera: Braconidae) in growing sugarcane plantations', Kasetsart Journal - Natural Science, 49(3), pp. 403-412.

Meng XB, Chen Q, Lu SC, Chen YN, L. Z. \& M. X. (1997) 'Techniques for forecasting the occurrence of Taiwan rice stem borer.', Acta Phytophylacica Sinica, 24, pp. 133-136.

Neupane, F. (1990) 'Status and control of Chilo spp. on cereal crops in southern Asia', Insect Science and its application, 11, pp. 501-534.

Nikpay A, Vejar-Cota, G, Budeguer, F, Qin, Z, Perera, MF \& Goebel, FR (2020) 'Agroecological of stem borers for healthy seed production in sugarcane', in Tiwari, A. K. (ed.) Advances in seed production and management. Springer Nature Singapore, pp. 43-77.

Ntiri, E. S. et al. (2016) 'Influence of temperature on intra- And interspecific resource utilization within a community of lepidopteran maize stemborers', PLoS ONE, 11(2). doi: 10.1371/journal.pone.0148735.

Nurindah, Sunarto, D. A., S. (2020) 'Overview of the use of biocontrol agents in the control of Indonesian sugarcane borers', IOP Conference Series: Earth and Environmental Science, 418(1). doi: 10.1088/17551315/418/1/012061. 
Ofomata, V. C. et al. (2000) 'Comparative studies on the fecundity, egg survival, larval feeding, and development of Chilo partellus and Chilo orichalcociliellus (Lepidoptera: Crambidae) on five grasses', Annals of the Entomological Society of America, 93(3), pp. 492-499. doi: $10.1603 / 0013-$ 8746(2000)093[0492:CSOTFE]2.0.C $\mathrm{O} ; 2$.

Pandya HV, Patel CB, Patel JR, Patel MB \& Patel KK. (1996) 'The problems of sugarcane borers in Gujarat, India', Cooperative Sugar, 28, pp. 293-294.

Rochat J, Goebel FR, Tabone E, Begue LJM, Fernandez E, Tibere R, Gauvin JC, Vercambre B. (2001) 'Integrated control of the sugarcane spotted stalk borer Chilo sacchariphagus (Lep: Pyralidae) in Reunion Island.', Proceedings of the Annual Congress of the South African Sugar Technologists' Association, 75, pp. 253-254.

Sallam, M. N. S. (2006) 'A review of sugarcane stem borers and their natural enemies in Asia and Indian Ocean Islands: An Australian perspective', Annales de la Societe Entomologique de France, 42(3-4), pp. 263-283. doi: 10.1080/00379271.2006.10697459.

Sallam N, Achadian E, Kristini A, Sochib M, Adi H (2010) 'Monitoring sugarcane moth borers in Indonesia: Towards better preparedness for exotic incursions', 32nd Annual Conference of the Australian Society of Sugar Cane Technologists 2010, ASSCT 2010, 32, pp. 181-192.

Sallam N, Achadian E, Putra L, Dianpratiwi T, Kristini A, Donald D, Magarey R. (2014) 'In search of varietal resistance to sugarcane moth borers in Indonesia', Proc Aust Soc Sugar Cane Technol, 36, pp. 183-187.

Sampson MA \& Kumar R (1986) 'Alternative Host Plants of SugarCane Stem-Borers in Southern Ghana', International Journal of Tropical Insect Science, 7, pp. 539541.

doi: https://doi.org/10.1017/S17427584000 09802.

Sardana HR \& Das DK (2001) 'Regression modelling to predict sugarcane stalk borer, Chilo auricilius', Indian Journal of Entomology, 63(4), pp. 435-438.

SAS Institute Inc. 2011. SAS/STAT® 9.3 User's Guide. Cary, NC: SAS Institute Inc

Singh PB \& Varma A. (1995) 'Population dynamics of the sugarcane shoot borer, Chilo infuscatellus Snellen in Andhra Pradesh', Annals of Plant Protection Sciences, 3, pp. 23-26

Sunaryo, S. J. S. (1986) 'Augmentation of Local and Introduction of Thailand Strain of Apanteles flavipes (Cam) in Gunung Madu Plantation, Lampung, Indonesia', Proc. of the Pakistan Society of Sugar Technologists, 22, pp. 153-159. 